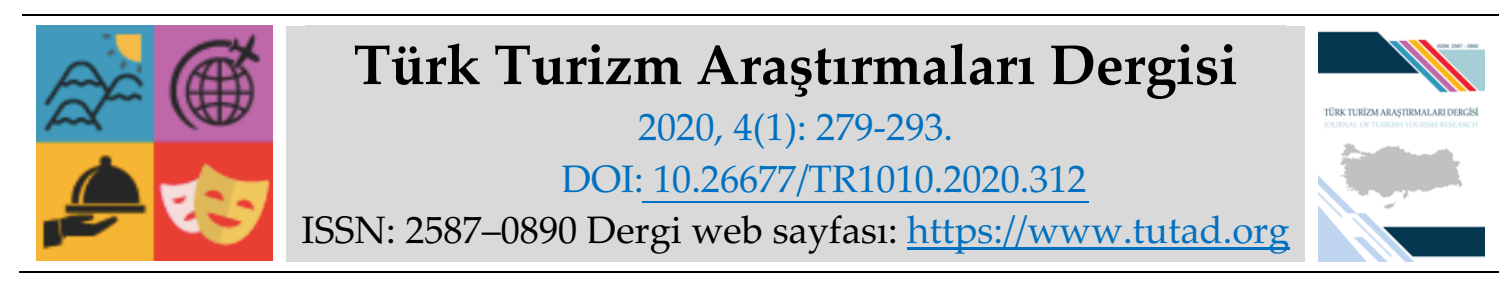

ARASTTIRMA MAKALESI

\title{
Zihinsel Engelli Çocuklara Sahip Ailelerin Yaşadıkları Tatil Güçlükleri Üzerine Tanımlayıcı Bir Araştırma
}

Dr. Öğretim Üyesi Funda ODUNCUOĞLU, Aydın Adnan Menderes Üniversitesi, Söke İşletme Fakültesi, Aydın, e-posta: funda.cengiz@adu.edu.tr ORCID: https://orcid.org/0000-0003-3273-8651

Öz

Tüm dünyada giderek önemi artan engelli turizmi pazarının özelliklerini daha iyi anlamak ve buna uygun pazarlama stratejileri geliştirmek adına bu pazarın iç dinamiklerine inerek farklı engel türlerini ve onların seyahatleri süresince yaşadıkları problemleri yakından incelemek gerekmektedir. Bu bağlamda çalışmanın amacı, tüm engel türleri arasında belki de en dezavantajlı yapıda olan zihinsel engelli bireylerin ailelerinin tatilleri öncesinde ve süresince, içsel ve dışsal faktörlere bağlı olarak yaşadıkları güçlükleri belirlemektir. Araştırma kapsamında 17 zihinsel engelli bireyin aileleri ile yarı yapılandırılmış mülakatlar gerçekleştirilmiştir. Araştırma sonucunda ailelerin tatil için temel motivasyonlarının çocuklarının mutluluğu olduğu, tatilin onları günlük stres ve kaygılardan arındırmada önemli bir araç olduğu, hemen hemen tüm ailelerin tatile ilişkin benzer sorunları yaşadığı sonuçlarına ulaşılmıştır.

Anahtar Kelimeler: Zihinsel Engelli Bireyler, Engelli Turizmi, Turizm.

Makale Gönderme Tarihi: 02.10.2019

Makale Kabul Tarihi: 13.01 .2020

\section{Önerilen Atıf:}

Oduncuoğlu, F. (2020). Zihinsel Engelli Çocuklara Sahip Ailelerin Yaşadıkları Tatil Güçlükleri Üzerine Tanımlayıcı Bir Araştırma, Türk Turizm Araştırmaları Dergisi, 4(1): 279-293.

(C) 2020 Türk Turizm Araştırmaları Dergisi. 


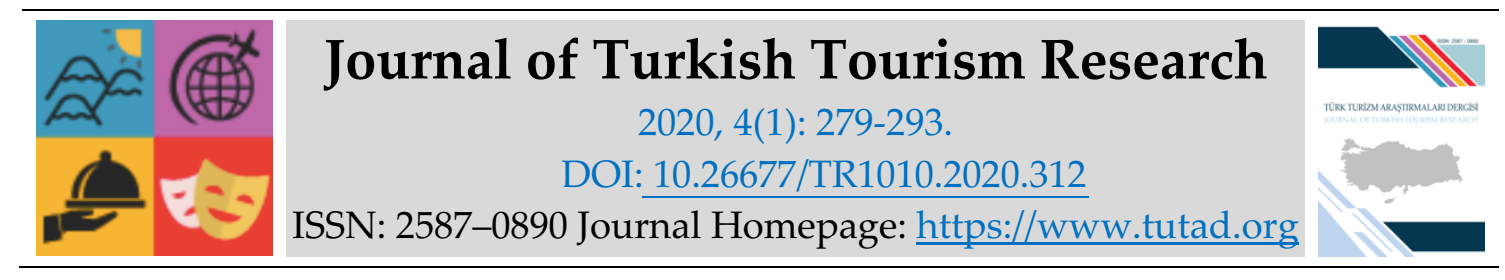

\title{
$\underline{\text { RESEARCH PAPER }}$
}

\section{A Descriptive Research on Holiday Difficulties of Families with Mentally Handicapped Children}

Dr. Öğretim Üyesi Funda ODUNCUOĞLU, Aydın Adnan Menderes University, Söke Faculty of Business, Aydın, e-mail: funda.cengiz@adu.edu.tr ORCID: https://orcid.org/0000-0003-3273-8651

\begin{abstract}
In order to better understand the characteristics of the disabled tourism market, which has become increasingly important all over the world and to develop appropriate marketing strategies, it is necessary to examine the different dynamics of the obstacles and their problems during their travels. In this context, the aim of the study is to determine the difficulties experienced by the families of mentally disabled individuals, who are perhaps the most disadvantaged among all types of disabilities, before and during the holidays due to internal and external factors. Semi-structured interviews were conducted with the families of 17 mentally disabled individuals. As a result of the study, it was concluded that the main motivation of families for the holiday is the happiness of their children, that the holiday is an important tool in relieving them from daily stress and anxiety, and that almost all families experience similar problems.
\end{abstract}

Keywords: Mentally Disabled Individuals, Disabled Tourism, Tourism.

Received: 02.10.2019

Accepted: 13.01 .2020

\section{Suggested Citation:}

Oduncuoğlu, F. (2020). A Descriptive Research on Holiday Difficulties of Families with Mentally Handicapped Children, Journal of Turkish Tourism Research, 4(1): 279-293.

(C) 2020 Türk Turizm Araştırmaları Dergisi. 


\section{Gíriş}

Engelli turizmi, engelli bireylerin oluşturduğu turizm aktivitesine ve seyahatlere verilen isimdir. Engelli turizmi, tüm dünyadaki engelli sayısının fazlalığı ve bu kişilerin genellikle tek başlarına değil yanlarında refakatçi veya refakatçileriyle seyahat ettikleri düşünüldüğünde turizm işletmeleri için çok değerli bir pazar anlamına gelmektedir. Engelli turizmi, sosyal turizm ve sağlık turizmi altında yer alan bir turizm türüdür. Engelli turizminin gelişimi için özellikle İkinci Dünya Savaşı'ndan sonra yapılan ve engellilerin turizm faaliyetlerine erişim engellerini ortadan kaldırmaya yönelik düzenlemeler ve yasalar, pazarın hızla gelişimini tetiklemiştir. Pazarın giderek büyüyen hacmi dışında, engelli turistlerin genellikle sonbahar ve ilkbahar aylarında seyahat etmeleri, ülkelerin turizm sezonlarını uzatıı bir etki yaratmakta olup, turizm gelirlerini arttırmak isteyen ülkeler açısından engellileri önemli bir pazar konumuna getirmiştir (Toker ve Kaçmaz, 2015:236). Pazarın öneminde gözlemlenen bu artışa ve engelli insanların da diğer insanlar gibi turizm faaliyetlerine katılmalarının en doğal hak olarak görülmesine karşın, turizm faaliyetleri sanki engelli olmayan kişiler için tasarlanmış şekildedir (Yau vd., 2004:946). Yau vd., (2004:947) bu durumu, turizm konusunda engelli bireylerin de diğerleri gibi aynı istek ve ihtiyaçlara sahip oldukları ancak, öncelikli olarak engelli olmayan bireylere yönelik tasarlanmış seyahatin, engelli bireyler için bazı zorluklar taşıyacağı şeklinde ele almaktadır. Söz konusu kısıtların, turizm alanlarında engelli bireylere yönelik düzenlemeler konusunda olabileceği gibi, engelli bireylerin istek, ihtiyaç, motivasyon ve beklentilerinin doğru şekilde anlaşılamamasından kaynaklı olabileceği de söylenebilir.

Engellilik heterojen bir yapıya sahiptir. Engelliliğin çeşitli şekilleri (cinsiyet, yaş, ırk/etnisite, kültür, sosyo-ekonomik durum, cinsel yönelim vb.) turist deneyimlerini farklılaştırmaktadır. Hatta benzer engelli grubu içerisinde engellilik düzeyinin tipine ve seviyesine göre farklı seyahat şekilleri planlamak gerekmektedir (Small vd., 2012:944). Bununla birlikte, farklı engele sahip bireylerin, farklı istek ve gereksinimleri de olacağı düşünüldüğünde, engellilik durumu ve çeşitlendirilmesinin önemi ortaya çıkmaktadır.

Kendi içinde farklı engel türlerine göre alt pazarlara ayrılan engelli pazarının alt pazarlarından birisi de zihinsel engelli bireylerin oluşturduğu pazardır. Zihinsel engelliler hayatları boyunca belli bir zeka seviyesinde kalan fakat düşük bir algılama yetisine sahip bireylerdir (Göktaş ve Bulgan, 2016:40). Zihinsel engelli kavramını tanımlamak, en başta bu bireyleri tanımak ve gereksinimlerini karşılayacak uygulamaları gerçekleştirmek için önem taşımaktadır. Zihinsel engellilik, zihinsel işlevlerde ortalamadan önemli derecede geride olma ve zihinsel işlevlerle ilişkili uyumsal beceri alanlarından (iletişim, özbakım, sağlık ve güvenlik, işlevsel akademik beceriler vb.) iki ya da daha fazlasında sınırlılıklar gösterme durumu olarak ifade edilmektedir (Eripek, 2004:26).

Zihinsel engelli bireyler sahip oldukları engel nedeni ile diğer engel türlerine sahip bireylere göre bağımsız seyahat etmek konusunda çok kısıtlıdırlar. Bu bireyler tatillerinde mutlaka yanlarında bir ya da birden fazla refakatçi ile seyahat etmektedirler. Çarpan etki yaratması nedeni ile azımsanmayacak bir pazar oluşturan zihinsel engelliler, seyahatleri süresince pek çok engelle karşılaşmaktadır. Zihinsel engelliler tüm engel grupları içerisinde gerek psikolojik gerekse sosyal anlamda desteklenmesi gereken en önemli azınlığ temsil etmektedir. Bu engel grubuna sahip olanların yanı sıra ailelerinin de ilgi ve desteğe ihtiyaçları vardır (Özşenol vd., 2003:160).

İngiliz Üniversitesi Surrey tarafından yürütülen OSSATE (One-Stop-Shop Accessible Tourism in Europe- Avrupa'da Erişilebilir Turizm) adlı çalışma, Avrupa'da 46 milyona yakın fiziksel ya da zihinsel sorunu bulunan engellinin yaşadığı sonucunu ortaya koymaktadır (Zengin ve Eryılmaz, 
2013:54). Türkiye'de ise engelli olan nüfusun toplam nüfus içindeki oranı $\% 12.29$ olup yaklaşık 8 milyon kişidir. Ülkemizdeki ortopedik $(\% 1,25)$, görme $(\% 0,60)$, işitme $(\% 0,37)$, dil ve konuşma $(\% 0,38)$ ile zihinsel özürlülerin $(\% 0,48)$ sayısı 1,8 milyon kişi, diğer bir ifade ile $\% 2.58$ oranındadır. Bu oranın ise \%3.05'i erkek, \%2,12'si ise kadınlardan oluşmaktadır. Süre gelen hastalığı olanların oranı ise 6,6 milyon kişi yani \%9,70 oranındadır ve bu oranın \%8,05'i erkek ve \%11,33'ü kadınlardan oluşmaktadır (TÜİK, 2011). Yapılan araştırmalar sonucunda engelli nüfusun \%70'inin seyahat ettiği belirlenmiştir. Engelli bireylerin genellikle bir ya da birkaç kişinin refakatiyle seyahat ettikleri düşünüldüğünde ise Avrupa' da seyahat eden potansiyel rakamın 130 milyon kişi ve bunların yaklaşık turizm harcamasının 80 milyar Euro'dan fazla olduğu düşünülmektedir (TÜRSAB, 2008). Rakamlardan da anlaşılacağı üzere günümüzde, turizm endüstrisi için engelliler önemli bir pazar konumundadır ancak buna rağmen gerek sektörel gerekse akademik anlamda bugüne kadar bu önemli pazarın üzerine fazla düşülmemiştir (İsraeli 2002:101; Yau vd., 2004:947; Öztürk vd., 2008:388). Engelli insanların da diğer insanlar gibi turizm faaliyetlerine katılmaları en doğal hakları olmasına rağmen, turizm faaliyetleri engelli bireyleri göz ardı eder biçimde tasarımlanmış şekildedir (Yau vd., 2004:947).

Engellerle yaşamak birçok güçlügü de beraberinde getirmektedir. Kabul edilen görüşe göre, turizm faaliyetlerine katılmak engelli olan ve olmayan tüm insanlar için gerekli bir aktivitedir. Ancak, engellilerin turizm faaliyetlerine katılma ve mutlu olmaları için sosyal ve pratik olarak değişik türde güçlüklerin üstesinden gelmeleri gerekmektedir (Germ ve Schleien, 1997:27). Bir engelli için konaklama faaliyeti bir bilet satın alma, rezervasyon veya paket tur için ödeme yapmak kadar basit bir eylem değildir. Engellilerin ve onlarla seyahat eden bireylerin tam katılımlarını engelleyen pek çok pratik ve sosyal engel bulunmaktadır (Yau vd., 2004:948). Engelli kişiler diğer insanlardan farklı olarak, özel ihtiyaçlarına uyum sağlayacak elverişli ulaşım araçlarına, konaklama işletmelerine, çeşitli restoran hizmetlerine ve eğlence aktivitelerine gereksinim duymaktadır. Engellilerin diğer insanlardan ayrı nitelikte olan özellikleri dikkate alındığında, bu grubu oluşturan müşterilerin konfora, güvenliğe ve erişime gereksinim duyması kaçınılmazdır, ancak engelli turizmi özellikle ulaşım ve konaklama tesislerine yönelik ilave yatırım ve maliyet gerektirdiği için turizm yatırımcıları, bu pazara mesafeli durmakta ve özellikle Türkiye'de yasal zorunluluk sınırı olan toplam oda sayısının \%1'i düzeyinin üzerine çıkmamaktadır (Yıldız vd., 2017:64).

Engellileri sosyal hayata katmak ve onların daha iyi bir hayat sürdürmesi için çalışmalar yapmak, birer sosyal sorumluluk örneğidir. Geçmişten günümüze engelliler sıklıkla ekonomik, sosyal ve siyasi yapı bozuklukları, bilgi eksikliği, yanlış yaklaşımlar, olumsuz tutumlar, ayrımcılık ve fiziksel çevre koşullarının yetersizliği gibi sorunlarla karşılaşmıştır (Tütüncü ve Aydın,2013:261). Huh ve Singh (2007:220) çalışmalarında ABD'de yaşayan ve engelli bir üyeye sahip aileler için turizm endüstrisinin uygunluğunu araştırmışlardır. ABD nüfus raporları ve 6 eyaletin seyahat piyasası araştırmalarından elde edilen ikincil verilerin kullanıldığ çalışmada ampirik bulgular indirimli anlaşmalar, otomobil kulüp yayınları ve özel dizayn edilmiş web siteleri ile bu piyasanın cazip olacağını göstermektedir. Engellilerin daha çok hangi çeşit ve türde tatil ile ilgilendiklerine dair Bergier vd., (2010: 1136-1137) çalışma bulguları önem arz etmektedir. Buna göre Engellilerin \%66'sı ulusal turları, \%15'i rehabilite-spa merkezlerini, \%12'si aileleri ile birlikte, \%3.9 bahçe ve rekreasyonu, \%1.3 ü ise uluslararası turu tercih etmektedirler. Huh ve Singh (2007: 221) çalışmasında, engelli bir üyenin bulunduğu ailelerin son 12 ayda hangi sıklıkla seyahat ettiği bilgisine ilişkin şu sonuçları bulmuştur: Ailelerin \%49.5'i 1-3; \%28'i 4-6; \%11.8'i 10-20; \%6.1'i 7-9 arasında seyahat gerçekleştirmiştir. Huh ve Singh (2007: 221) çalışmasında, engelli bir üyenin bulunduğu ailelerin tercih ettiği seyahat çeşidine ilişkin şu sonuçları bulmuştur: Ailelerin \%85.6's1 gecelik konaklama, \%14.4'ü ise günübirlik konaklamayı tercih etmektedir. Engellilerin hangi çeşit tatile ilgi gösterdiklerine yönelik Zbikowski vd. (2011:125), tarafından yapılan çalışma 
bulguları önemlidir. Buna göre engellilerin önemli bir kısmı rehber eşliğinde turistik gezileri daha çok tercih etmektedirler.

Türkiye'de nüfusun \%18'i çeşitli ruhsal sorunlarla yaşamının en az bir döneminde ruh sağlığ 1 kurumlarına başvurmakta. 1,5 milyon civarında ise zihinsel engelli birey olduğu bilinmekte. Yakınları de hesaba katıldığında en az 20 milyon kişinin bu sorundan doğrudan ya da dolaylı olarak etkilendiği söylenebilir (www.engelliler.biz). Toplum çapındaki damgalama ve ayrımcılık nedeniyle ruhsal sorunlar yaşayan ve zihinsel engelli bireyler çoğunlukla yalıtılmış yaşamlar yaşamakta ve toplumsal yaşamın pek çok alanının dişında kalmaktadır (www.engelliler.biz). Türkiye'nin belirli bölgelerinde psiko sosyal ya da zihinsel engelli bireyleri evin dişarına bile çıkarmayan aileler bulunmaktadır. Pazara, zihinsel engelli bireyler açısından yaklaşan akademik çalışmalar incelendiğinde ise, bu bireylerin çözmekte güçlük yaşadıkları pek çok seyahat engellinin olduğu görülmektedir. Özellikle zihinsel engelli bireylerin ailelerinin refakati ile gerçekleşen turizm aktiviteleri düşünülecek olunursa; zihinsel engelli bireye sahip ebeveynlerin diğer sağlıklı bireylere sahip ebeveynlere göre daha stresli bir yapılarının oluşu nedeniyle, bu tür aktivitelere katılım onlar açısından daha da zordur. Bu tür ebeveynler; panik duygusuna, korkuya, kaygıya ve üzüntülü bir ruh haline sahiptir (Israeli,2002:103, Poria vd., 2011:572). Farklı özelliklere sahip bir bireyin anne ve babası olma rolü, ebeveynlerin kendisini önceden hazırladığ1 bir rol değildir (Sarı, 2007:1). Ailenin kendisini hazırlamadığı bu durumu kabullenmesi duygusal olarak zorlayıcı bir durumdur. Aileler keder, bakım yükünün uzaması, sosyal etiketlenme ve ebeveynlik açısından rol modeli eksikliği nedeniyle duygusal yüklenmeler yaşamaktadır. Bunun yanı sıra, kendilerinden ya da toplumdan kaynaklanan nedenlerle sosyal izolasyon, çocuğun bakım sorumluluklarının fazla olması nedeniyle de fiziksel yüklenme yaşayabilmektedir. Tüm bu zorluklar, ekonomik güçlükler ile birleştiğinde ailenin duygusal zorlanmaları artmaktadır (Sarı, 2007:2). Ülkemizde zihinsel engelli çocukların ebeveynleriyle gerçekleştirilen araştırmalar onların zihinsel engelli çocuğu olmayan ebeveynlerden daha depresif ve kaygılı olduklarını (Aysan ve Özben, 2007:3; Dereli ve Okur, 2008:160), suçluluk, utanç duyguları yaşadıklarını (Karaçengel, 2007:83), çocuklarının gelecekteki bakımına ilişkin endişeler taşıdıklarını ve çocuğun aile yaşamına getirdiği sınırlılıklar, ömür boyu bakımının getireceği zorluklardan kaynaklanan kaygılara sahip olduklarını ortaya koymuştur.

Yetersizliği olan bir çocuğun varlı̆̆ına başarılı bir şekilde uyum yapmayı kolaylaştıran ve yaşamlarında hissettikleri stres düzeyinin azalmasını sağlayan en önemli faktörlerden biri sosyal destektir. Sosyal destek, bireyin diğer insanlardan aldığı yardıma işaret etmektedir. Kişinin sevildiği, değerli bulunduğu, kabul edildiği ve kişiler arası destek ağının bir parçası olduğu inancına sahip olmasını sağlayan bilgi olarak tanımlanabilir. Bireyler, sosyal desteği eşi, ailesi ve arkadaşlarının yanı sıra boş zaman etkinliklerinden, tatil ve eğlence aktivitelerinden, toplum programlarından ve profesyonel kişi ile kurumlardan alabilir (Siklos ve Kerns, 2006: 923). Zihinsel engelli çocukların ebeveynlerinin yaşadıkları duygusal güçlükleri, stres algılarını inceleyen araştırmalarda sosyal destek algısı sıklıkla ele alınan bağımsız değişkenlerden biri olmaktadır. Sosyal destek ile ilgili olarak gerçekleştirilen araştırmalar, engelli çocuklara sahip bireylerin sosyal destekleri arttıkça psikolojik belirtilerinin (Arslan, 2010:74), umutsuzluk düzeylerinin (Köksal ve Kabasakal, 2012:73), depresif belirti ve stres düzeylerinin azaldığını; uyumlarının (Bailey, 2007), iyi olma durumlarının (White ve Hastings, 2004:184) arttığını ortaya koymuştur. Engelli bireylerin kendi başlarına bağımsız olarak hareketlerinin sağlanması oldukça zor olsa da imkansız değildir. Engellilere yönelik turizm erişilebilirliğine ilişkin çalışmalar bulunsa da zihinsel engellilere özgü yapılan çalışmaların yetersiz olduğu bilinmektedir (Waieland ve Baker, 2010:626). Zihinsel engelli bireylerin ve refakatçilerinin turizm faaliyetlerine kolay erişebilmesi noktasında tüm servis sağlayıcılarının (otel, restoran, bar, müze, eğlence parkları vb. alanların) erişilebilirliğinin sağlanması dikkate alınması gereken unsurlardandır. 
Pozitif personel tutumu özellikle zihinsel engelli bireylerin turizm sektöründeki tesislerin erişilememesi açı̆̆ını hafifletmek için yardımcı olabilecek belki de en önemli etmendir. Turizm sektöründe zihinsel engellilerin karşılaşabilecekleri bariyerleri ortadan kaldırarak, engellilere eğitilmiş ve olumlu tutumlar sergileyen personelle hizmet sunmak, onların memnuniyetlerini en üst seviyeye taşıyarak, seyahat ve turizm hizmetlerini aldıkları işletmelere tekrar gelmelerini sağlayacaktır (Israeli, 2002:101-102).

Bulgan'ın 2017 yılında Isparta ilinde yaşayan 371 zihinsel engelli bireye sahip aileye uyguladığ anket sonucunda, araştırmaya katılan zihinsel engellilerin ailelerinin eğitim durumları ve aylık gelir durumlarının düşük seviyelerde olduğu tespit edilmiş ve zihinsel engellilerin aktif olarak turizm faaliyetlerinde bulunamadıkları belirlenmiştir. Tatil için en çok Antalya'yı tercih eden hedef kitlenin, tatil kararı almalarında eş ve dostlarının tavsiyelerinin etkili olduğu sonucuna ulaşılmıştır (Bulgan,2017).

Holden engellilerin seyahat ve turizm endüstrisinde yasadıkları problemlerin oldukça az çalışma ile irdelendiğini yaptığı araştırmada vurgulamaktadır. $\mathrm{Bu}$ nedenle seyahat ve turizm endüstrisinin erişilebilirliğini yeniden değerlendirmeye ihtiyaç duyulmakta olduğuna vurgu yapan Holden, engelli bireylerin refakatçi ile seyahat etmek zorunda olduğunu ve engelli bireylerin birlikte seyahat ettikleri refakatçileri ile hiçbir güçlük yaşamadan herkes gibi eşit şekilde turizm servis sağlayıcılarından yararlanmak isteyebileceklerinin de göz önünde bulundurulması gerektiğine değinmiştir. Araştırmada elde edilen bulgulara göre, refakatçinin ve engelli aile bireyinin seyahat ve turizm deneyimleri oldukça farklı bileşenlerden oluşmaktadır. $\mathrm{Bu}$ bileşenler doğrultusunda seyahatlerini planlama, seyahat hazırlığı yapma, erişilebilirlik sorunu, beklentileri ve engelli aile bireyinin fiziksel gereksinimleri dikkate alınmalıdır (Bulgan, 2017:2148).

Tütüncü ve Aydın (2013), çalışmalarında, engelli bireylerin aileleri ile birlikte değerlendirildiğinde sayıca 2 milyar kişiye ulaştıklarını ve bu sayının da dünya nüfusunun 3 'te birini oluşturmakta olduğu için turizm faaliyetlerinin bu önemli kitle için ulaşılabilir kılınması gerektiğini vurgulamaktadırlar. Çalışmada yaşlı veya engelli olan bireylerin ve bu bireylerin ailelerinin tatile çıkarken kısıtlarının olması, seyahat etmek ve turizm faaliyetlerinde bulunmanın bu bireyler için büyük bir soruna dönüşmekte oluşu ve bu insanlar için seyahat etmenin genelde zor, pahalı ve zaman alıcı olduğuna değinilmektedir. (Tütüncü ve Aydın, 2013: 262).

Kim ve Lehto (2013) yaptıkları araştırmada, engelli çocuklara sahip olan ailelerin seyahatlerini aktivite ve motivasyon açısından ele almaktadır. Yazarlara çalışmalarında 161 Koreli engelli çocuğu bulanan aile üzerinde turizm aktivite ve motivasyon düzeylerini araştırmışlardır. Faktör analizinden faydalanılarak 5 motivasyon faktörü ve 7 aktivite faktörü belirlenmiştir. Araştırma sonucunda, engelli çocuğa sahip olan ailelerde en önemli motivasyon faktörünün "engelli çocuklarda fiziksel yeterlilik" olduğunu belirttikleri, "oturarak yapılan açık hava etkinlikleri"nin de aile gezileri sırasında yapılan en önemli aktivite olduğu tespit edilmiştir. Ayrıca bu çalışma seyahat motivasyonları ve aktivite alanları arasındaki ilişkiyi inceleyerek, her ikisinin arasında anlamlı bir bağlantının olduğunu ortaya çıkarmıştır (Kim ve Lehto, 2013:16).

Zihinsel engelli bireyleri konu alan akademik çalışmalar genel olarak değerlendirildiğinde, turizm için önemli bir Pazar dilimini oluşturmalarına karşın bu alana ilişkin çalışmaların henüz sınırlı sayıda olduğu ve geliştirilmeye ihtiyaç duyduğu öncelikli vurgu yapılan konu olarak karşımıza çımaktadır. Benzer biçimde konuyla ilgili araştırmalarda, zihinsel engelli bireylerin ve yanlarında refakat eden ailelerin tatil ihtiyaçlarının diğer insanlardan farklı olmadığı ancak tatilleri süresince pek çok engel ile karşılaştıkları ve bu engellerin gerek tatile çıkma motivasyonlarını gerekse tatil süreçlerini olumsuz yönde etkilediği dikkat çekilen diğer bir konu 
olmuştur. Son olarak, gerek zihinsel engelli bireylerin gerekse ebeveynlerinin rutin hayatlarında yaşadıkları stresi ve kaygıyı azaltmada tatilin önemli bir rol oynadığı da çalışmaların ortak bulgularındandır.

\section{YÖNTEM}

Çalışmanın veri toplama yöntemi nitel araştırma yöntemlerinden yarı yapılandırılmış görüşmedir. Bu yöntemin tercih edilmesindeki ilk neden, alan yazında engelli bireylere ilişkin nicel çalışmalara yer verilmekle birlikte bu konuda yapılmış nitel çalışmaların son derece az olması ve katılımcıların derinlemesine görüşlerine ulaşılabilmesidir. Bu yöntemin tercih edilmesindeki diğer önemli nedenler ise; araştırmacının aktif olarak sürece katılımının sağlanması, araştırma amacı doğrultusunda derinlemesine bilgiye ihtiyaç duyulması ve bu bilgilerin ebeveynlerden direk alınmasının uygun bulunmasıdır. Görüşme formu, yazın taramasına bağlı olarak geliştirilmiştir. Yarı yapılandırılmış görüşme tekniği daha esnek ve görüşme sonucunda ulaşılan bulguların zengin ve derinlemesine olmasına imkan sağlar (Kümbetoğlu, 2015: 75). Bu nedenle araştırmada bu görüşme tekniği tercih edilmiştir., Hazırlanan formda açı uçlu sorulara yer verilmekle birlikte yarı yapılandırılmış sorulara da yer verilmiştir.

Tablo 1- Görüşme Soruları

1-Zihinsel engelli çocuğunuz için seyahatin bir hak olarak görüldüğünü düşünüyor musunuz? 2-Zihinsel engelli çocuğunuz için turizme katılmak onları ve siz aileleri nasıl etkilemektedir?

3- Zihinsel engelli çocuğunuz ve siz ailelerin seyahat engellerinin aşılması için sizce neler yapılmalıdır?

4- Aşağıda yer alan ifadelerden hangisi/hangileri tatiliniz süresince yaşadığınız en önemli güçlüklerdir?

- Yetersiz bilgi,

- Sosyal beceri yetersizliği,

- Sağlığa bağlı nedenler,

- Fiziksel ve psikolojik nedenler

- Ekonomik yetersizlik,

- Gelir farklılıkları,

- Engellilerin seyahatlerinde birilerine ihtiyaç duymaları

- Turistik mekanlara (tarihi yerler, rekreasyon alanları vb.) ulaşmada problemler

- Konaklama yerlerine ulaşmada problemler

- Ulaştırma

- Güvenlik

- Kurallardan ve yönetmeliklerden doğan problemler,

- Yeterli beceriye sahip olmama,

- Konuşma yeteneğinin az olması,

- Aktivitelere katılmada cesaretin olmaması,

- Konaklama işletmelerinde çalışanların tutumu

Nitel araştırmalar genelleme yapma amacı taşımadığından, incelenen olay ya da olguyu ölçmekten ziyade derinlemesine anlamaya çalışmak daha önemlidir. Bu nedenle geniş bir örneklem kitlesiyle çalışmak yerine araştırmanın amacına uygun küçük bir örneklem grubuyla çalışılması daha faydalı olmaktadır. Dolayısıyla nitel araştırmalarda sıklıkla amaçlı örnekleme yöntemi kullanılmaktadır. Amaçlı örneklemin mantı̆̆ı ve gücü derinlikli çalışmalar için bilgi 
açısından zengin durumlar seçilmesini sağlar (Glesne, 2013:32). Bu bağlamda araştırmanın örneklem seçiminde yaş sınırlamasına gidilmiştir. Çocukların içinde bulunduğu gelişim dönemleri, ebeveynlerin stres algısı üzerinde etkide bulunabilecek bir faktördür. Zihinsel engelli bir çocuğun bebeklik ya da ergenlik döneminde ailelerin başa çıkmak durumunda kalacağ sorunların nitelikleri farklı olacaktır. Bu nedenle araştırma örneklemi, sadece aynı yaş grubundaki (6-12 yaş) zihinsel engelli çocukların ebeveynlerinden seçilmiştir. Bu araştırma kapsamında, belirlenen ölçütler neticesinde Aydın'da faaliyet gösteren özel bir eğitim ve rehabilitasyon merkezinde tedavi gören 17 zihinsel engelli çocuğun ebeveynlerine ulaşılmıştır ve birebir görüşmeler gerçekleştirilmiştir. Görüşmeler Mayıs-Temmuz 2019 tarihleri arasında gerçekleştirilmiştir. Görüşmelerde öncelikle örneklem grubuna demografik ve seyahat biçimlerine ilişkin kapalı uçlu sorular sorulmuş ardından da Tablo 1'de yer alan 4 ana soru çerçevesinde görüşmeler yapılmıştır.

Görüşmeler yüz yüze gerçekleştirilmiş, her bir görüşme ortalama bir saat kadar sürmüş, görüşmelerde eksik ya da atlanan veri kaybını önlemek adına ses kayıt cihazı kullanılmış ve görüşme sonrasında katılımcıların görüşleri yazıya dökülmüştür.

\section{BULGULAR}

Araştırmadan elde edilen bulgular kısmında, sorulara verilen yanıtlar her bir aileye kodlar verilerek aktarılmaya çalışılmıştır. Örneğin, Aile1 (A1), Aile 2 (A2), Aile 3 (A3) şeklinde. Aile bireylerinden kasıt anne ve babadır. Her iki ebeveynin de araştırma sorularına ortak görüşlerini belirtmesi istenmiştir. Katılımcıların turizm hareketlerine katılmadaki motivasyonlarını ve beklentilerini belirleyen unsurlar çeşitlilik göstermekle birlikte, sorulara verilen yanıtların anlamsal olarak benzeştiği ve önemli noktalara temas ettiği dikkati çekmektedir.

Araştırmaya katılan katılımcıların demografik özelliklerine ilişkin bulgular Tablo 2'de sunulmuştur. Aşağıda yer alan tablo 2 incelendiğinde, araştırmaya katılan ailelerin sahip olduğu engelli çocuk sayısının 15 ailede 1 çocuk ile sınırlı olduğu görülmektedir. Buna karşın 1 aile 2 engelli çocuk, bir diğer aile ise 3 engelli çocuğa sahip olduklarını belirtmişlerdir. Ailelerin yıl içinde gerçekleştirdikleri tatil sayısına ilişkin bulguya bakıldığında ailelerin çoğunlukla yıl içinde 2 ve 3 defa tatile çıtıkları görülmektedir. Tatil tercihlerine ilişkin bulgu da ise yüksek oranda tercihlerini yurtiçi tatillerden yana kullandıkları görülmektedir. Ailelerin sahip olduğu aylık gelire ilişkin bulgu da ise belirli bir gelir aralığında toplanma olmadığı ve araştırmaya katılan ailelerin farklı gelir aralıklarında olduğu ancak çoğunluğun 5000-9000 TL aralığında aylık gelire sahip olduğu görülmektedir. Ailelerin eğitim seviyelerine ilişkin bulguda da aylık gelirle benzer biçimde farklı eğitim seviyelerinde ailelerin olduğu görülmektedir.

Araştırmaya katılan katılımcıların görüşme sorularına verdikleri bulgular ise aşağıdaki biçimde gerçekleşmiştir

\section{Görüşme sorusu 1: Zihinsel engelli bireyler için tatile çıkmanın bir hak olarak görüldüğünü düşünüyor musunuz?}

Konuya ilişkin yapılan araştırmalarda, engelli bireyler için tatile çıkmanın bir hak olarak görülmediği, ötesinde tatillerinde dışlandıkları ve yadırgandıkları ve bu durumun onların seyahat motivasyonunu olumsuz yönde etkilediği ya da tamamen seyahat etme isteğini ortadan kaldırdığı belirtilmektedir. $\mathrm{Bu}$ bağlamda katılımcılara kendilerinin konuya ilişkin ne düşündükleri ve çocukları için tatile çıkma hakkını nasıl algıladıklarına ilişkin bu soru 
yöneltilmiştir. Katılımcıların tamamı zihinsel engelli çocukları için tatilin bir hak olduğunu düşündüklerini belirtmişlerdir. Araştırmaya katılan ailelerin soruya ilişkin verdiği yanıtlardan bazıları aşağıdaki biçimde gerçekleşmiştir.

A13- "Düşünüyorum, sonuç olarak onun da bir birey olarak diğer insanlardan bir farkı yok".

A14- "Tabi ki düşünüyorum, engelli demek yaşamamak değildir! Hatta onlar normal insanlardan daha güzel yaşamayı hak ediyorlar".

A8- "Evet, düşünüyorum, ancak çevresel faktörlerden dolayı zorlanıyoruz."

A10- "Tabi ki düşünüyorum, ancak etraftaki zorluklar nedeniyle toplu taşıma seyahati gerçekleştiremiyoruz."

Aile 13 ve 14 soruya verdikleri yanıtlarda daha çok çocuklarının da normal bir birey gibi tatile çıkma hakkı olduğuna vurgu yaparken, Aile 8 ve 10 ise her ne kadar bir hak olduğunu düşünseler de çevresel faktörlerin onları tatil fikrinden alıkoyduğuna vurgu yapmışlardır.

Tablo 2. Katılımciların Demografik Bilgileri

\begin{tabular}{l|l|l|l}
\hline Sorular & Cevaplar & $\mathrm{n}$ & $\%$ \\
\hline Ailedeki engelli çocuk sayısı & 1 & 15 & 88 \\
& 2 & 1 & 6 \\
& 3 & 1 & 6 \\
& 4 ve üzeri & - & \\
\hline Yıl içinde gerçekleştirdiğiniz tatil sayısı & 1 & 4 & 22 \\
& 2 & 5 & 30 \\
& 3 & 5 & 30 \\
& 4 ve üzeri & 3 & 18 \\
\hline Tatil için tercihiniz & Yurtdışı & 2 & 12 \\
& Yurtiçi & 15 & 88 \\
\hline Aylık geliriniz & $1000-2999$ & 1 & 6 \\
& $3000-4999$ & 2 & 12 \\
& $5000-6999$ & 6 & 6 \\
& $7000-8999$ & 5 & 30 \\
& 9000 ve üzeri & 3 & 18 \\
\hline Eğitim seviyeniz & İlkokul & - & \\
& Ortaokul & 2 & 12 \\
& Lise & 6 & 34 \\
& Önlisans & 3 & 18 \\
& Lisans & 5 & 30 \\
& Yüksek lisans & 1 & 6 \\
& Doktora & - &
\end{tabular}

Görüşme sorusu 2: Zihinsel engelli bireyler için turizme katılmak onları ve siz aileleri nasıl etkilemektedir?

$\mathrm{Bu}$ sorunun katılımcılara yönetilmesindeki temel amaç, konuya ilişkin yapılan araştırmalarda seyahat ve tatilin ve genelinde sosyalleşmenin zihinsel engelli çocuğa sahip ailelerde günlük hayatlarında yaşadıkları stres, kaygı ve umutsuzluk düzeylerinde azalmaya neden olduğunun 
belirtilmesidir. Bu soruya verilen yanıtlar aracılığı ile araştırmaya katılan katılımcıların da benzer yönde bir bakış açısı ve psikolojiye sahip olup olmadıkları belirlenmek istenmiştir. Katılımcıların verdiği yanıtlar genel olarak değerlendirildiğinde de bulguların literatürü desteklediği sonucuna ulaşılmıştır. Ebeveynlerin büyük çoğunluğu, özellikle çocuklarının tatil süresince yaşadığı mutluluğa tanık olmanın onlar için en önemli motivasyon ve sevinç kaynağı olduğunu belirtmişlerdir. Araştırmaya ilişkin bazı ailelerin verdiği yanıtlar aşağıdaki biçimde gerçekleşmiştir.

A8- "Yılda iki kez, bayramlarda ailelerimizin yazlığına gidiyoruz. Tabi ki büyükler için yorucu oluyor, ancak çocuğumun mutluluğuna değiyor."

A17-“Çocuğumun kişisel gelişimi için çok iyi geliyor, sosyalleşiyor tabi ki biz de o mutlu olunca çok mutlu oluyoruz."

A15- "Rahatlıyoruz, krizlerimiz azalıyor!"

A11- “Kızımıza motivasyon sağlıyor, bizlere de tüm zorluklara rağmen mutluluk veriyor."

A1- "Birlikte bir şey yapmak bizi ailecek mutlu ediyor. Yaz tatilinden sonra kış tatili için motive oluyoruz."

Ailelerden A9 ve A4 ise her ne kadar tatilin çocukları ve kendileri için önemli bir rahatlama yolu olduğunu belirtseler de, özellikle tatilleri süresince çocuklarına karşı gösterilen anlayışsızlık ve tepkiler nedeni ile olumsuz yönde de etkilendiklerini belirtmişlerdir.

A9- Çevremizde bizi anlayan, çocuğumuz değişik sesler çıardığında ilk kez duymuş gibi dehşet saçan gözlerle bakmayan kişiler olduğunda muhteşem hissediyoruz. Ancak iki üç tatilimizi duyarsız kişiler nedeniyle yarıda bıraktık."

A4- "Çocuğumuza çok iyi geliyor, ancak biz çevremizdeki olumsuz bakışlar ve anlayışsız insanlar yüzünden çok geriliyoruz."

Görüşme sorusu 3: Zihinsel engelli çocuğunuz ve siz ailelerin seyahat engellerinin aşılması için sizce neler yapılmalıdır?

Araştırmanın kilit sorularından birisi olan 3. soruya verilen yanıtlar özellikle katılımcıların tatile ilişkin yaşadıkları sorunların aşılması için nelerin yapılmasını istediklerini ortaya koyabilmesi açısından önem taşımaktadır. Katılımcıların soruya verdiği yanıtlar genel olarak değerlendirildiğinde ortak görüşlerin "insanların duyarlı olması" ve "çalışanların eğitilmesi", "otellerde engellilere yönelik özel uygulamaların olması" vb. biçiminde gerçekleşmiştir.

Literatürde zihinsel engelli bireylerin ve onlara refakat edenlerin tatilleri süresince yaşadıkları sorunları inceleyen araştırmalarda karşılaşılan sorunların aşılması noktasında en çok dikkat çekilen ve önerilen konular turizm personelinin zihinsel engelli bireylere yaklaşım ve hizmet konusunda eğitilmesi, diğer insanların onları yadırgamayarak hoşgörü ile yaklaşmalarının sağlanması ve konaklama işletmeleri başta olmak üzere tüm turizm işletmelerinde onların rahat ve huzurlu tatil yapmalarını sağlayacak koşulların yaratılması gerekliliği olarak işaret edilmektedir. Bu araştırma sonucunda da zihinsel engelli bireylerin ebeveynlerinin soruya ilişkin verdikleri cevaplar benzer içerikte olmuştur.

Araştırmaya katılan katılımcılardan bazılarının 3. Soruya verdiği yanıtlar aşağıdaki biçimde gerçekleşmiştir. 
A1- Çevremizdeki insanların duyarlı olmasını istiyoruz."

A14- "Tatillerimizi genellikle otellerde geçirmekteyiz bu yüzden otel işletmelerinde engel türü ayırt etmeksizin çocuklarımıza özel eğlence alanlarının olmasını istiyoruz."

A3- "Toplu taşımalarda yolcular bildirilmeli, otellerde bizim çocuklarımız için uzman kişiler olmall."

A10- "Zihinsel engelli çocukların ve ailelerinin tatil yapabileceği özel otellerin olması gerekmektedir, oradaki insanlar birbirlerini anlayacakları için sorun da çımayacaktır."

A13-“ Engel türü ne olursa olsun, her tür engelin aşıldığı alanlar yaratılmalı ve tatil yapılan yerlerde hizmet sunan personeller bu konuda eğitilmeli."

A14-“Tekerlekli sandalye yolları yapılabilir, çocuklarımız için özel havuzlar yapılabilir. Eğlence yerleri onların ihtiyaçlarına göre düzenlenebilir. İşyerinde çalışan personele bu konu ile ilgili eğitim verilebilir."

A9- "Biz özel çocuk sahibi aileler olarak çocuklarımız için insanlardan çok fazla beklentimiz yok. Gittiğimiz yerlerde biz yokmuşuz gibi davranabilirler. Ne sempati ne de antipati istemiyoruz. Bizden çocuklarını kaçırmalarına gerek yok, bulaşıcı değiliz!"

Katılımcılara yöneltilen üç açı uçlu sorunun ardından 4. Soru da ise yarı yapılandırılmış bir görüşme sorusu yöneltilmiş ve literatürden derlenerek hazırlanan ailelerin tatilleri süresince yaşadıkları güçlükler 18 önerme biçiminde toplanarak, katılımcılara bu güçlüklerden hangilerini yaşadıklarını 5'li likert ölçeği üzerinden " 1 hiç katılmıyorum" ve "5 kesinlikle katıllyorum" biçiminde yanıtlamaları istenmiştir. 17 katılımcının verdikleri yanıtların frekans hesaplamaları yapılmıştır. 18 önermeye ilişkin sonuçlar incelendiğinde katılımcıların \%80 oranında 17 önermeye de "kesinlikle katılıyorum" biçiminde yanıt verdikleri sonucuna ulaşılmıştır. Katılımcıların düşük oranda yaşadıkları ve "hiç katılmıyorum" ve " katılmıyorum" biçiminde ifade ettikleri güçlükler ise "ekonomik yetersizlikler" ve "gelir farklılıkları" olmuştur. Bu önermelere ilişkin katılımcıların değerlendirmeleri genel olarak değerlendirildiğinde yaşanan sorunların ortak olması ile birlikte demografik bir değişken sayılabilecek gelir durumuna ilişkin önermeler ise katılımcıların değişik gelir seviyelerinde olmaları nedeni ile farklılık göstermiştir.

Görüşme formu sonunda katılımcılara belirtmek istedikleri başka bir düşünceleri olup olmadığı sorulmuştur. Bu soruya karşılık beş katılımcı ek görüş bildirmiştir. Bu görüşler aşağıdaki biçimdedir.

A14- "Otel çalışanlarına engelli bireylere nasıl davranılması gerektiği hakkında eğitim verilmelidir."

A7-“Özel bir çocuğa sahipseniz gittiğiniz her yerde tek düşünceniz ona zarar gelmemesi ve hor görülmemesidir. Bu konuda insanların daha duyarlı olması ve ailelere de manevi destek sağlanması gerektiğini düşünüyorum."

A6- "Tatillerde maddi imkanınız yüksekse daha az problem yaşıyorsunuz ancak çocuğunuzun krizleri ve istekleri durumunda anlıyorsunuz ki sadece siz varsınız."

A7-“Tatil yerlerinde farklı engelli türlerine sahip bireyler ve aileleri için özel düzenlemeler yapılmasının şart olduğunu düşünüyorum. En öncelikli şey ise personelin bizlere karşı güler yüzlü ve nazik olması, olmadığında tatil bizim için başlamadan bitiyor. Ayrıca ulaşımı 
kolaylaştıracak aparatların olması, özel masa, sandalye, oda gibi unsurların olması bizlerin işini kolaylaştırır.

A13- "İşyerlerinin çalışan personellerine engelli bireyler konusunda özel eğitimler vermesi gerektiğini ve bunun bir zorunluluk haline getirilmesi gerektiğini düşünüyorum."

Katılımcıların sorulardan ve önermelerden bağımsız olarak eklediği düşüncelere bakıldığında, çalışmanın genel bir özetini yaptıkları ve en net sorun yaşadıkları alanları tekrar vurguladıkları görülmektedir. Özellikle vurgu yapılan görüşler çalışma içerisinde de sıklıkla belirtilen personele yönelik eğitim, özel koşulların oluşturulması ve insanlar tarafında hoş görülme isteğidir.

\section{TARTIŞMA, SONUÇ VE ÖNERILLER}

Zihinsel engelli bireyler diğer engelli bireylere nazaran engel türleri nedeni ile bir refakatçi ile birlikte seyahat etmek durumundadırlar ve bu nedenle yarattıkları çarpan etki ile turizm sektörü için azımsanmayacak bir pazar oluşturmaktadırlar, Bu özellikli pazar grubunu oluşturan bireyler seyahatleri süresince pek çok engelle karşılaşmaktadırlar. Literatürde oldukça az çalışmada incelenen bu önemli pazarın geliştirilmesi adına bu araştırma konuyu geniş kapsamlı ele alarak zihinsel engelli bireylerin ailelerinin tatil davranışlarının incelemesi açısından önem arz etmektedir.

Nitel araştırma yönteminin kullanıldığı bu araştırmada engelli çocuğa sahip 17 ebeveynle yarı yapılandırılmış görüşme formu üzerinden yüz yüze görüşmeler gerçekleştirilmiş ve konunun bu yöntem aracılı̆̆ ile daha detaylı ve derinlemesine incelenmesi hedeflenmiştir. Araştırma sonucunda elde edilen bulgular konuya ilişkin gerek engelli turizmi gerekse özelinde zihinsel engelli bireylerin ailelerine ilişkin yapılmış turizm, tatil ve seyahat çalışmaları ile örtüşmektedir.

Araştırma sonucunda ailelerin tatil için temel motivasyonlarının çocuklarının mutluluğu olduğu, tatilin onları günlük stres ve kaygılardan arındırmada önemli bir araç olduğu elde edilen en önemli bulgulardan biridir. Zihinsel engelli bir bireyin ebeveyni olma aileleri duygusal olarak zorlayıcı ve ailenin bakım yükünü arttırıcı bir durumdur. Ayrıca, toplumdan dışlanma, bakımın maliyetli ve yorucu olması nedeniyle de fiziksel ve ekonomik güçlükler ailenin duygusal zorlanmalarını daha da artırmaktadır. Yapılan araştırmalar tatilin gerek zihinsel engelli bireyler gerekse aileleri için bu ağır duygusallıktan kurtularak kısa süreliğine de olsa pozitif duygular geliştirmelerinde önemli rol oynayan bir olgu olduğunu işaret etmektedir. Araştırmaya katılan katılımcıların da görüşleri tatilin bu yönünün onlar için ne denli önemli olduğunu ortaya koymaktadır.

Araştırmanın önemli bulgularından bir diğeri ebeveynlerin tamamının zihinsel engelli çocukları için tatil yapma isteğinin doğal bir istek olduğu ve buna hakları olduğunu düşündükleri bulgusudur. Literatürde de en çok dikkat çekilen seyahat engellerinden biri olan toplumsal dışlanma ve hor görülme durumlarına karşın ebeveynler çocuklarının da tatil yapma isteği olduğunu ve bu isteğin normal bireyler kadar onların da hakkı olduğunu ifade etmektedirler. Bu seyahat engelinin aşılması için toplumsal bilincin geliştirilmesi ve bu bireyleri rahatsızlıkları ile kabul eden bakış açısının hakim kılınması önem arz etmektedir.

Ailelerin tatilleri süresince yaşadıkları sorunlar görüşme formunda katılımcılara yöneltilen 18 önerme ile tespit edilmeye çalışılmıştır. Araştırmaya katılan ailelerinin tamamının tatillerine ilişkin benzer sorunlar yaşadığı tespit edilmiştir. Katılımcıların çocukların sahip olduğu engel 
nedeni ile yaşadıkları seyahat engelleri; "sosyal beceri yetersizliği", "sağlığa bağlı nedenler", "fiziksel ve psikolojik nedenler", "yeterli beceriye sahip olmama"," konuşma yeteneğinin az olması"," aktivitelere katılmada cesaretin olmaması" biçiminde sıralanabilirken, turizm işletmelerine ilişkin yaşadıkları engeller; "yetersiz bilgi", "turistik mekanlara ulaşmada problemler", "konaklama yerlerine ulaşmada problemler", "ulaştırma", "güvenlik" ve "konaklama işletmelerinde çalışanların tutumu" biçiminde sıralanabilir. Ailelerin kendilerine ilişkin yaşadıkları sorunlar ise; "engellilerin seyahatlerinde birilerine ihtiyaç duymaları", ve "kurallardan ve yönetmeliklerden doğan problemler" dir. Seyahat sürecine ilişkin engelleri gerek engel sahibi birey gerek işletme gerekse aile açısından ele alan önermelerde katılımcıların her üç açıdan da sorun yaşadığı ve literatürde işletmelerden kaynaklı sorunların dışında da bireylerden ve refaketçilerinden kaynaklanan temel sorunların olduğunu ortaya koyması açısından önemli bir bulgudur. Ayrıca katılımcılara yöneltilen ve aile ile ilgili sorun teşkil ettiği araştırmalarda vurgulanan "ekonomik yetersizlik" ve "gelir farklılıkları" sorunları ise katılımcılarca diğer sorunlardan farklı biçimde daha az önemli sorunlar olarak değerlendirilmiştir.

Çalışmadan elde edilen bulgular ışığında gerek sektöre gerekse akademik yazına bu pazarın gelişmesi ve sorunların aşılması noktasında ışık tutabilecek önerilerden ilki tatil için ailelerin çok özellikli ve farklı ihtiyaçlarının olmadığı ancak özellikle ulaşım ve konaklama konusunda gerçekleştirilecek bazı düzenlemelerle tatillerini çok daha kaliteli geçirebilecekleri bulgusundan hareketle bu düzenlemelerin neler olabileceği konusunda yeni araştırmalar yapılması ve sektörün bu konuda yönlendirilmesidir. Bir diğer öneri ise zihinsel engelli bireylere ve ebeveynlerine hizmet sunan personelin hassas, güler yüzlü ve eğitimli olmasının katılımcıların tatil motivasyonunu ve tatminini arttırıcı önemli bir faktör olduğu bulgusundan hareketle özellikle konaklama işletmelerinde bu pazarın geliştirilebilmesi adına personele eğitimlerin verilmesi ve bu eğitimlerin içeriğini konu alan akademik çalışmaların yapılmasıdır. Bir diğer öneri, ebeveynlerin tatilleri süresince birlikte konakladıkları diğer misafirlerin de kendilerine ve çocuklarına karşı hassas ve anlayışlı davranmasını arzu ettikleri bulgusundan hareketle toplumsal anlayışın geliştirilerek bakış açısının değiştirilmesi adına turistik destinasyonların yerel yönetimlerinin ve sektör kuruluşlarının iş birliği içinde çalışmalar yapması ve bu bilinci aşılamaya çalışmalarıdır. Son olarak getirilebilecek öneri ise, bundan sonra konuya ilişkin yapılacak akademik çalışmalarda konunun daha fazla katılımlı ve nicel açıdan incelenmesi, konunun işletmeler açısından nasıl algılandığı, işletmelerin mevcut durumlarının pazar için yeterliliği vb. konular araştırılarak pazara ilişkin daha kapsamlı bilgilerin elde edilmesidir.

\section{KAYNAKÇA}

Aslan, Ç. (2010). Zihinsel Engelli Çocuğu olan Anne-Babaların Psikolojik Belirtileri, Sosyal Destek Algıları ve Stresle Başa Çıkma Tarzlarının Karşılaştırılması, Yayınlanmamış Yüksek Lisans Tezi, Maltepe Üniversitesi Sosyal Bilimler Enstitüsü, İstanbul.

Aysan, F. ve Özben, Ş. (2007). Engelli Çocuğu Olan Anne Babaların Yaşam Kalitelerine İlişkin Değişkenlerin İncelenmesi, Buca Eğitim Fakültesi Dergisi. 22: 1-6.

Bailey, D. (2007). Introduction: Family Adaptation to Intellectual and Developmental Disabilities. Mental Retardation and Developmental Disabilities Research Reviews: 13: 291-292 
Bergier, B., Bergier, J. and Kubinska, Z. (2010). Environmental Determinants of Participation in Tourism and Recreation of People with Varying Degrees of Disability. Journal of Toxicology and Environmental Health, 73: 1134-1140.

Bulgan, G. (2017). Zihinsel Engelli Bireylere Sahip Ailelerin Tatil Deneyimleri Üzerine Tanımlayıcı Bir Araştırma: Isparta İli Örneği, İstanbul Sosyal Bilimler Dergisi, 16: 2147- 3390.

Dereli, F. ve Okur, S. (2008). Engelli Çocuğa Sahip Ailelerin Depresyon Durumunun Belirlenmesi, Yeni Tip Dergisi, 25: 158-164.

Eripek, S. (2004). Türkiye'de Zihin Engelli Çocukların Kaynaştırılmalarına İlişkin Olarak Yapılan Araştırmaların Gözden Geçirilmesi, Ankara Üniversitesi Eğitim Bilimleri Fakültesi Özel Eğitim Dergisi, 5 (2): 25-32.

Germ, P.A. and Schleien, S.J. (1997). Inclusive Community Leisure Services: Responsibilities of Key Players, Therapeutic Recreation Journal 31: 22-37.

Glesne, C. (2013). Nitel Araştırmaya Giriş. 2. Baskı (A. Ersoy ve P. Yalçınoğlu, Çev.), Ankara: Anı Yayıncilik

Göktaş, P. ve Bulgan, G. (2016). Turizm Sektöründe Engelliler ile İletişimin Geliştirilmesine Yönelik Bir Çalışma, Erciyes İletişim Dergisi, 43: 36-56.

Huh, C., and Singh, A. J. (2007). Families travelling with a disabled member: Analysing the potential of an emerging niche market segment. Tourism and Hospitality Research, 7 (3/4): 212-229.

https://www.engelliler.biz/forum/sakatlik-calismalari-inisiyatifi/128030-turkiye-de-psikososyalve-zihinsel-engelli-bireylerin-durumu-ve-cozum-onerileri.html [Erişim tarihi: 12.08.2109].

Israeli, A., A. (2002). A Preliminary Investigation of the Importance of Site Accessibility Factors for Disabled Tourists, Journal of Travel Research, 41 (1): 101-104.

Karaçengel, B. (2007). Zihinsel Engelli çocuğa sahip anneler ile sağlıklı çocuğa sahip annelerin atılganlık ve suçluluk-utanç düzeyleri açısından karşılaştırılması. Yayınlanmamış Yüksek Lisans Tezi. Maltepe Üniversitesi. Sosyal Bilimler Enstitüsü, İstanbul

Kim, S. and Lehto, X. Y. (2013). Travel by Families with Children Possessing Disabilities: Motives and Activities, Tourism Management, 37: 13-24.

Köksal, G., and Kabasakal, Z. (2012). Zihinsel Engelli Çocukları Olan Ebeveynlerin Yaşamlarında Algıladıkları Stresi Yordayan Faktörlerin İncelenmesi, Buca Ĕ̆itim Fakültesi Dergisi, 32: 71-91.

Kümbetoğlu, B. (2005). Sosyolojide ve Antropolojide Niteliksel Yöntem ve Araştırma, İstanbul: Bağlam Yayıncilik.

Özşenol, F., Işıkhan, V., Ünay, B., Aydın, H. İ., Akın, R., ve Gökçay, E. (2003). Engelli Çocuğa Sahip Ailelerin Aile İşlevlerinin Değerlendirilmesi, Gülhane Tıp Dergisi 45 (2): 156-164. 
Öztürk, Y., Yaylı, A., Yeşiltaş, M. (2008). Is the Turkish Tourism Industry Ready for a Disabled Customer's Market?, Tourism Management, 29(2): 382-389.

Poria, Y., Reichel, A. and Brandt, Y. (2011). Dimensions of Hotel Experience of People with Disabilities: An Exploratory Study, International Journal of Contemporary Hospitality Management, 23 (5): 571-579.

Sarı, H. (2007). Zihinsel Engelli Çocuğu Olan Ailelerde Aile Yüklenmesi, Cumhuriyet Üniversitesi Hemşirelik Yüksekokulu Dergisi, 11 (2), 1-7.

Siklos, S. and Kerrns, K. (2006). Assessing Need for Social Support in Parents of Children with Autism and Down Syndrome, Journal of Autism Development Disorders, 36: 921-933.

Toker, B. ve Kaçmaz, Y. Y. (2015). Engelli Bireylerin Turizm Deneyimlerine Yönelik Bir Araştırma: Alanya Örneği, Dokuz Eylül Üniversitesi Sosyal Bilimler Enstitüsü Dergisi, 17(2): 235-257.

Tütüncü, Ö. ve Aydın, Đ., (2013). Ulaşılabilir Turizm, Anatolia: Turizm Araştırmaları Dergisi, 24 (2): 261-263.

Türkiye İstatistik Kurumu Haber Bülteni (2011). Özürlülerin Sorun ve Beklentileri Araştırması 2010, Sayı:71.

Türkiye Seyahat Acenteleri Birliği (2008). Dünyada ve Türkiye'de Engelsiz Turizm Pazarı Ar-Ge Departmanı Raporu.

Waieland, N. and Baker, L. (2010). The role of marital quality and spousal support in behaviour problems of children with and without intellectual disability. Journal of Intellectual Disability Research, 54 (7): 620-633.

White, N. and Hastings, R. (2004). Social and Professional Support for Parents of Adolescents with Severe Intellectual Disabilities, Journal of Applied Research in Intellectual Disabilities, 17: 181190.

Yau, M. K., McKercher, B. and Packer, T. L. (2004). Traveling with a Disability: More Than an Access Issue, Annals of Tourism Research, 31 (4): 946-960.

Yıldız, Z., Yıldız,S., Karaçayır, E. (2017). Dünyada ve Türkiye'de Engelli Turizmi Pazarının Değerlendirilmesi, Journal of Tourism and Gastronomy Studies, 5(2): 61-80.

Zbikowski, J., Kuzmicki, M., Dabrowski, D., and Soroka, A. (2011). Vocational Activity as a Determinant of Participation in Tourism of Disabled People from the Area of Eastern Poland, Oeconomia, 10 (2): 121-129.

Zengin, B. ve Eryılmaz, B. (2013). Bodrum Destinasyonunda Engelli Turizm Pazarının Değerlendirilmesi, International Journal of Economic and Administrative Studies, 6(11): 52-74. 